\title{
Vankien koulutuksesta
}

\author{
TUULA AAMUVUORI
}

L _okakuussa 2006 voimaan tulevan vankeuslain mukaan yksi vankeuden täytäntöönpanon tavoitteista on lisätä vangin valmiuksia rikoksettomaan elämäntapaan edistämällä vangin elämänhallintaa ja sijoittumista yhteiskuntaan sekä estää rikosten tekeminen rangaistusaikana (vankeuslaki 2§).

Saman lain mukaan vankeuden sisältönä on vapauden menetys tai sen rajoittaminen. Vankeuden täytäntöönpano ei saa aiheuttaa vangin oikeuksiin eikä olosuhteisiin muita rajoituksia kuin niitä, joista säädetään lailla tai jotka välttämättä seuraavat itse rangaistuksesta.

Lain mukaan vangille on laadittava yksilöllinen suunnitelma rangaistusajan suorittamisesta, vapauttamista ja ehdonalaista vapautta varten. Suunnitelman tulee sisältää mm. toiminnasta vankeusaikana. Toiminnan tarkoitus ja sisältö on myös määritelty ja sen yhtenä tavoitteena on ylläpitämällä ja parantamalla vangin ammattitaitoa ja osaamista sekä työ- ja toimintakykyä edistää vangin sijoittumista yhteiskuntaan. Lisäksi vangin koulutuksesta on samassa vankeuslain säädetty vangeille oikeus osallistua vankilassa tai sen ulkopuolella järjestettävään koulutukseen.

Vangille, joka ei ole suorittanut perusopetuksen oppimäärää, on annettava tilaisuus sen suorittamiseen. Lisäksi vangin opintoja on ohjattavaja tuettava sekä opiskelumenestystä seurattava. Koulutuksesta annettavasta todistuksesta ei saa ilmetä, että opintoja on harjoitettu vankilassa.

Edellä on pääpiirteissään ne lainkohdat, jotka säätelevät myös opiskelua vankilassa. Eriasia on, kuinka em. lain kohtia eri vankiloissa voidaan toteuttaa.

Tässä jutussa painottuu itäsuomalainen näkökulma siitä syystä, että en ole työskennellyt muualla kuin Kuopion tutkintavankilassa. Vankilaan tulevat entisen Keski-Suomen läänin ja entisen Kuopion läänin alueelta rikoksesta vangitut miespuoliset tutkintavangit, joiden tuomiot ovat vielä vailla lainvoimaa. Jonkin verran Kuopion vankilaan on sijoitettu myös rangaistustaan suorittavia vankeja (vankeusvankeja).
Tutkintavangilla ei ole velvollisuutta osallistua toimintaan. Sen sijaan he saavat halutessaan osallistua toimintoihin. He voivat siis myös opiskella, mutta heidän opiskelunsa ei ole este siirtää heitä toiseen laitokseen.

\section{Ehtona motivaatio opiskella}

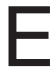

nnen kuin vanki aloittaa opiskelemaan, on oltava motivaatio opiskeluun.

Vangin opiskeluhalua hallitsee melko usein jokin muu kuin halu lisätä tietoa. Koska vankeusvanki joka tapauksessa on velvollinen osallistumaan toimintaan, opiskelu saattaa houkutella näennäisellä helppoudellaan; se helppous tosin karisee melko nopeasti ensimmäisten tenttien tullessa.

Yhtenä opiskelumotiivina saattaa olla siirto vapaampiin oloihin tai toisaalta lupaus siitä, että opiskeluaikana ei siirretä toiseen vankilaan. Toinen vankila täällä Kuopiossa voisi olla esimerkiksi Sukevan vankila lisalmen ja Kajaanin puolivälissä. Kaupunkivankilassa olisi kivempi olla, kaveritkin pääsisivät tapaamaan, siispä opiskelemaan.

Jos lähdetään tyvestä puuhun, niin ensin suoritetaan peruskoulu. Sen suorittaminen on mahdollista kaikissa Suomen vankiloissa. Joissakin vankiloissa aikuislukio järjestää perusopetusta. Ellei opetusta voida järjestää vankilassa, vankiloiden opinto-ohjaajat ovat joko itse ohjanneet, mahdollisesti jopa opettaneet yksittäisiä vankeja tai ainakin hankkineet joko kielten tai matemaattisten aineiden tukiopetusta vankilaan.

Jonkin verran näitä peruskoulutodistuksen puutteessa olevia vankeja on. Ongelma joidenkin kohdalla on se, että kouluajasta on kulunut vuosia eikä tietojen päivittäminen onnistukaan ihan hetkessä. On muistettava, että vankilassa ollaan tekemisissä niiden opiskelijoiden kanssa, jotka silloin aikoinaan kuusivuotiaina ovat saaneet rokotuksen koulua vastaan ja sen antama suoja on kestänyt koko peruskoulun ajan. Vankiopiskelijoiden osalta on soveltuvin osin noudatettava niitä pykäliä, mitä asianomaisesta koulu- 
tuksesta yleisesti säädetään, ts. vankiopiskelijankin on suoriuduttava tietyn tasoisista tenteistä saadakseen peruskoulunsa suoritetuksi. Ihan kuin sivilissäkin, peruskoulu on koko ikäluokan koulu. Sen sijaan esimerkiksi lukio on sitten oma lukunsa.

Sitten mennään joko lukioon tai ammatilliseen oppilaitokseen

\section{Etälukio soveltuu vankiloihin}

$\mathrm{M}$ yös lukio-opetusta on aikuislukion järjestämänä vankilassa. Sellaisissa vankiloissa, joissa ei ole lukio-opiskelijoiden ryhmää, etälukio antaa oivan mahdollisuuden lukion suorittamiseen. Katselen siis edelleen tätä opiskeluasiaa Itä-Suomesta Kuopiosta käsin ja ainakin meillä etälukiota ei voi mainita kuin kiitosten kera. Lukion suorittamisen voi käytännössä aloittaa kuuden viikon välein, aineistoa saa niin opettajilta kuin netinkin välityksellä, opettajat ovat tiettyinä aikoina puhelimen päässä, tentit valvotaan vankilassa ja tulokset tulevat nopeasti.

Opiskelijalta etälukio ehkä vaatii enemmän kuin ryhmässä opiskelevalta ja etälukiolainen on opiskelussaan yksinäinen; vertaistukea ei ole eikä mahdollisuutta verrata menestystään kurssikaverin kanssa. Tietää vain sen, että samaan aikaan, kun opiskelija tenttii vankilassa, parikymmentä muuta opiskelijaa jossakin luokkahuoneessa pähkäilee juuri samojen kysymysten kimpussa.

Koska Kuopion vankila on ns. tutkintavankila ja joka ei ole vangin lopullinen sijoitusvankila, lukio-opiskelijoita, jotka ovat käyneet koko lukion ja suorittaneet ylioppilastutkinnon, taitaa olla vain pari kappaletta. Sen sijaan osasuorituksia meilläkin on, toivottavasti opiskeluintoa on ollut vielä seuraavassakin vankilassa tai seuraavalla tuomiolla.

\section{Ammattikoulutusta vankiloissa}

$J_{0}$ os vanki haluaa suorittaa ammatillisen koulutuksen, sekin on mahdollista vankilassa. Vankeinhoitolaitos toteuttaa yhdessä eri ammatillisten oppilaitosten kanssa useita erilaisia ammatillisen koulutuksen kursseja. Lisäksi vankiloissa voidaan järjestää oppisopimuskoulutusta niillä työaloilla, jotka kuuluvat vankilan arkeen.

Usein kuulee kritiikkiä siitä, että koulutuksessa kyllä on paljon vankeja, mutta suoritettujen tutkintojen määrä on vähäinen. Vankeinhoitovä- ellä on tähän selitys: nykyään koko ammattitutkinnon suorittaminen vie noin kolme vuotta. Kolmen vuoden tuomio on melko pitkä, harvalla opiskelevalla vangilla tuomio riittää koko tutkinnon suorittamiseen ja koska, koska vapaana ei vankilasta käsin voi opiskella, tutkinto vankeusaikana jää suorittamatta. Me täällä vankilassa emme itse asiassa tiedäläheskään aina, onko opiskelija suorittanut tutkintonsa vapauduttuaan.

\section{Siviiliopiskelu avovankiloista käsin}

A vovankiloista käsin vangin on myös mahdollista opiskella läsnäolevana missä tahansa oppilaitoksessa. Edellytyksenä on se, että vanki on hyväksytty oppilaitoksen opiskelijaksi. Ns. siviiliopiskelija on siis päivät oppilaitoksessa, noudattaa oppilaitoksen opintosuunnitelmaa ihan niin kuin muutkin. Hän vaan asuu muista opiskelijoista poiketen laitoksessa. Eipä taida Kuopiossakaan olla yhtään oppilaitosta, jossa ei jossakin vaiheessa olisi ollut vanki opiskelijana, ihan yliopistosta saakka.

Siviilissä opiskelevat vangit ovat kertoneet, että heillä on melkoisia paineita, joista pienin ei varmaankaan ole se, kertooko vanki opiskelevansa vankilasta. Silloin, kun vanki hakee siviiliopintolupaa, henkilökunta kertoo oppilaitoksen rehtorille, oppilaitoksen kuraattorille ja mahdollisesti myös linjajohtajalle, että opiskelija käy vankilasta, mutta luokkakavereille kertominen jää vangin itsensä ratkaistavaksi. Vangit pelkäävät sitä, että he jäävät yksin, mikäli kertovat olevansa vankeja. Mutta käytäntö on osoittanut, että kyllä se yksinjääminen ennemminkin johtuu henkilön persoonasta kuin siitä, missä yönsä viettää.

\section{Vapautuminen on kriittinen taite}

$\mathrm{V}$ angin vapautuminen on aina kriittinen piste, nivelkohta. Vankilassa opiskeleminen on vangin kannalta halpaa ja helppoa; on ruokaa, on asunto, vaatetuksestakin pidetään huolta ja houkutuksia on vähän. Siviilissä on toisin: on asuntohuolet, huoli toimeentulosta, sosiaalinen elämäkin vie osansa. Aika monella vankilaan tullessaan on ongelmia päihteiden kanssaja koska vankilat ovat päihteettömiä laitoksia, houkutus aloittaa käyttö uudelleen on suuri.

Opiskelunsa keskeyttäneiden määrästä minulla ei ole tietoa, mutta ne opiskelijat, joihin olen siviilissä törmännyt, ovat kertoneet, että ryhmäy- 
tyminen siviiliopiskelijoihin ja heidän antamansa tuki on auttanut heitä jatkamaan opintojaan, vaikka vaikeuksia on ollut. Mikäli opiskelumotivaatio on ollut oikea, opiskelu jatkuu vaikeuksista huolimatta.

\section{Erityisryhmän erityisopiskelu}

$V_{\text {arrestan }}$

angeista melko monella on lukiongelma. Vasta viime aikoina on aikuisten lukiongelmaan ruvettu kiinnittämään huomiota myös vankeinhoitolaitoksessa. Meillä Kuopiossa käy lukiopettaja kerran viikossa, tulijoita olisi enemmän kuin opettajan aikatauluun mahtuu. Lukihäiriöepäilyjä on myös, ongelmana on testaaminen. Enemmän resurssia tulisi olla. Tuntuu siltä, että ne opiskelijat, jotka ovat ääneen kertoneet ongelmastaan ja lähteneet opetukseen, ovat olleet tosi tyytyväi- siä ratkaisuunsa. Pää on noussut pystympään, kun kirjaimet ja sanat ovat alkaneet käyttäytyä ymmärrettävästi.

Silloin joskus, kun vankiloita perustettiin, opiskelua vankiloissa ei ollut. Niinpä vankilat, joissa vangilla olisi aikaa opiskella, sijaitsevat maaseudulla. Vankilaan on hankala saada opettajia, sen sijaan opiskelijoita saattaisi olla. Kaupunkeihin, hyvien liikenneyhteyksien ulottuville, perustettiin tutkintavankiloita, joissa vangit ovat tuomionsa alkuvaiheet. Silloin odotetaan oikeudenkäyntiä tai mahdollista mielentilatutkimusta. Päässä pyörivät aluksi ihan muut ajatukset kuin opiskeluun liittyvät. Paikkakunnilla olisi opettajia, mutta ei opiskelevia vankeja. Tässä mielessä ainakaan täällä ltä-Suomessa kysyntä ja tarjonta eivät vankiopiskelijoiden kohdalla kohtaa toisiaan.

\section{Vankien opiskelusta pähkinänkuoressa}

Noin seitsemällä prosentilla vangeista on jäänyt peruskoulu kesken, kun muun väestön vastaava osuus on alle promillen. Vangeilla on paljon koulutusvajeita ja myös oppimisvaikeuksia. Noin neljä prosenttia vangeista on suorittanut lukion.

Vangeilta saatujen haastattelutietojen mukaan noin puolella heistä ei ole mitään ammatillista koulutusta, kolmasosa on suorittanut ammatillisien tutkinnon ja loput ovat osallistuneet johonkin lyhyehköön ammatilliseen kurssiin.

Päivittäin opiskelee noin 10 prosenttia vangeista, kun taas työtoimintaan osallistuu noin 40 prosenttia vangeista. Vuonna 2004 opiskeli jonkinmuotoisesti 1665 vankia. Peruskoulun päästötodistuksen suoritti 24 vankia, lukion päästötodistuksen sai seitsemän ja ylioppilastutkinnon suoritti niin ikään seitsemän vankia.

\section{Opiskelun perusjakauma:}

Alkeisopetus 90 vankia

Perusopetus 432

Lukio-opetus 147 166

Valmentava

Ammatillinen 907

Korkeakoulu 17

Muut 50

YHTEENSÄ 1809
$5 \%$ vankeista 24

\section{8}

9

50
3

\section{Opiskelual raavasti:}

Ohjaava, valmentava

ja kuntouttava koulutus

Tietotekniikka

Auto- ja kuljetusala

Kone- ja metallialat

Käsi- ja taideteollisuus

Kauppa ja hallinto

Maatalous, metsätalous ja

puutarhatalous 62

Matkailu, ravitsemus, talous 38

Puuala

Kauneudenhoito

Hieroja/ kuntosaliohjaaja

Sähköala

LVI

Muut

YHTEENSÄ

Vankilan ulkopuolella opiskeli 170 vankia, joista $56 \%$ ammatillisissa oppilaitoksissa, $14 \%$ aikuiskoulutuskeskuksissa ja 17 \% korkeakouluissa ja yliopistoissa. Oppisopimuskoulutuksessa oli 87 vankia. Romanivankeille järjestettyä luku- ja kirjoitustaidon sekä romanikulttuurin opetukseen osallistui viisi vankia.

LÄHDE: Vankeinhoitolaitoksen vuosikertomus 2004, Vankeinhoito. (www. rikosseuraamus. fi) 